\title{
Agreement on Overt Disseminated Intravascular Coagulation in Sepsis Patients between International Society of Thrombosis and Haemostasis Criteria and Japanese Ministry of Health and Welfare Criteria
}

\author{
Dwika Audiyananda, Leni Lismayanti, Basti Andriyoko \\ Department of Clinical Pathology Faculty of Medicine Universitas Padjadjaran \\ Dr. Hasan Sadikin General Hospital Bandung, Indonesia
}

\begin{abstract}
Disseminated Intravascular Coagulation (DIC) is an acquired syndrome characterized by the activation of intravascular coagulation which is most commonly caused by sepsis. There are two types of DIC disease: overt and non-overt DICs. The International Society of Thrombosis and Haemostasis (ISTH) criteria are more frequently used in the diagnosis of overt DIC compared to Japanese Ministry of Health and Welfare (JMHW). One of the different parameters of the two criteria is the D-Dimer element in the ISTH criteria and Fibrin Degradation Products (FDP) in the JMHW criteria. The availability of fibrin-related markers is different in each health center. This study aimed to see the agreement of the DIC diagnosis based on the ISTH and JMHW criteria and to analyze the correlation between D-Dimer and FDP in sepsis patients to help clinician decide which criteria is better to use. An analytical cross-sectional study was carried out on patients with sepsis based on the clinical diagnosis from the laboratory order forms and the DIC criteria according to the ISTH and JMHW. Patients included in this study were those visiting Dr. Hasan Sadikin General Hospital Bandung from August 2019-April 2020. Data collected were analyzed statistically using Cohen's Kappa test and Spearman test, both were performed in SPSS 17.0 program.There were 35 subjects participating in this study with overt and non-overt DIC with a composition based on the ISTH and JMHW criteria of 31 and 19 vs. 4 and 16, respectively. The Kappa coefficient between ISTH and JMHW was 0.266 ( $p$ 0.021) and the correlation between the D-Dimer and the FDP was 0.88 based on the Spearman test. There is a fair agreement on the DIC diagnosis and strong correlation between the FDP and the D-Dimer in sepsis patients when assessed using the ISTH and JMHW criteria. Both criteria are equally able to assist clinicians in determining the type of DIC depending on the type of fibrin-related markers available in the health centers.
\end{abstract}

Keywords: DIC, fibrin-related markers ,ISTH, JMHW, sepsis

\section{Kesesuaian Disseminated Intravascular Coagulation (DIC) Overt Berdasarkan Kriteria International Society of Thrombosis and Haemostasis dan Japanese Ministry of Health and Welfare pada Pasien Sepsis}

\begin{abstract}
Abstrak
Disseminated intravascular coagulation (DIC) adalah sindrom yang ditandai aktivasi koagulasi intravaskular yang paling sering disebabkan oleh sepsis. Tahap penyakit DIC diklasifikasikan menjadi DIC overt (tidak terkompensasi) dan DIC non overt (terkompensasi). Kriteria International Society of Thrombosis and Haemostasis (ISTH) lebih sering digunakan dibanding dengan Japanese Ministry of Health and Welfare (JMHW). Salah satu parameter yang berbeda dari kedua kriteria adalah fibrin-related marker berupa D-Dimer pada ISTH dan fibrin degradation products (FDP) pada JMHW. Ketersediaan jenis fibrin-related marker berbeda di tiap pusat kesehatan. Penelitian ini bertujuan melihat kesesuaian diagnosis DIC berdasarkan kriteria ISTH dan JMHW dan menganalisis korelasi D-Dimer dengan FDP pada pasien sepsis. Penelitian analitik dengan desain potong lintang dilakukan pada pasien dengan diagnosis sepsis berdasar atas keterangan klinis di formulir permintaan laboratorium dan kriteria DIC menurut ISTH dan JMHW di RSUP Dr. Hasan Sadikin Bandung pada bulan Agustus 2019-April 2020. Analisis statistik uji Cohen's Kappa dan Spearman diolah menggunakan program SPSS 17.0. Sebanyak 35 subjek dengan DIC overt dan non-overt berdasar atas kriteria ISTH dan JMHW adalah 31 vs 19 dan 4 vs 16. Koefisien Kappa antara ISTH dan JMHW adalah 0,266 (p=0,021). Ditemukan korelasi kuat antara D-Dimer dan FDP, yaitu 0,88 menggunakan uji Spearman. Terdapat kesesuaian diagnosis DIC yang cukup dan korelasi kuat antara FDP dan D-Dimer pada pasien sepsis antara kriteria ISTH dan JMHW. Kedua kriteria sama sama dapat membantu klinisi dalam menentukan tipe DIC bergantung pada ketersediaan jenis fibrin-related markers di tiap pusat kesehatan.
\end{abstract}

Kata kunci: DIC, fibrin-related markers, ISTH, JMHW, sepsis

Corresponding author: Dwika Audiyananda, Department of Clinical Pathology Faculty of Medicine Universitas Padjadjaran/Dr. HasanSadikinGeneralHospitalBandungJl.PasteurNo.38Bandung,WestJava,Indonesia,Email:dr.dwikaaudiyananda@gmail.com 


\section{Introduction}

Sepsis is a life-threatening organ dysfunction caused by dysregulation of the host's response to infection. In sepsis, the pathogen-initiated immune response fails to maintain haemostasis, giving rise to a pathological syndrome characterized by severe, persistent inflammation and suppression of the immune system. Sepsis is associated with strong activation of the coagulation system resulting in Disseminated Intravascular Coagulation (DIC), which is clinically characterized by the formation of microvascular thrombosis to consumption of clotting factors and platelets that cause bleeding. ${ }^{1}$

The International Society on Thrombosis and Haemostasis (ISTH) defines DIC as a syndrome characterized by acquired the intravascular coagulation which arise from various causes. This condition could be caused by trauma, vascular disorders, obstetric complications or malignancy. ${ }^{2,3}$

The stage of DIC is classified into 2 types, which are overt DIC (uncompensated DIC) and non-overt DIC (compensated DIC). The mortality rate in patients with overt DIC by $78 \%$ compared to non-overt DIC by $26.1 \% .{ }^{4}$ There are several criteria in determining the overt condition of DIC, including criteria from ISTH, the Japanese Ministry of Health and Welfare (JMWH), the Japanese Association for Acute Medicine (JAAM) and the Korean Society on Thrombosis and Hemostasis (KSTH). Early classification of DIC is very important to determine the management and prognosis of the patient. ${ }^{4}$ a simple tool to quickly establish DIC diagnosis is required. The purpose of this study was to introduce the simple and reliable tool for the prediction of outcome in patients with sepsis complicated by coagulopathy. We investigated the performance of simplified Japanese Society on Thrombosis and Hemostasis (JSTH).

The diagnostic criteria for ISTH was released in 2001 by the Scientific and Standardization Committee (SSC) of the International Society of Thrombosis and Hemostasis (ISTH) Subcommittee on DIC by calculating data on platelet counts, prolongation of Prothrombin Time (PT), fibrinogen levels and measurements from D-Dimer as reference for determining the value of the DIC score. Score more than 5 shows the condition of overt DIC with a worse prognosis. The ISTH score below 5 does not eliminate the possibility of DIC but indicates that it is in a compensated state. ISTH are currently widely used in the world. The drawback of the ISTH criteria is that it is less sensitive in diagnosing DIC conditions in the early phase. ${ }^{5}$

The JMHW criteria is a scoring system that was first created in 1987 to determine the diagnosis of overt DIC. The JMHW criteria were assessed based on the platelet count, the calculation of the International Normalized Ratio (INR), the measurement of Fibrin Degradation Products (FDP) and the levels of fibrinogen. The JMHW criteria also assessed the symptoms of the underlying disease, signs of bleeding and signs of organ failure as assessed by the clinician. ${ }^{6,7}$

FDP and D-Dimer are measure the end products of cross-linked fibrin degeneration by the action of plasmin in the fibrinolytic system. ${ }^{6}$ Elevated FDP levels indicate activation of plasmin and are often used to evaluate a primary fibrinogenolysis. ${ }^{8}$ D-Dimer is a part of the FDP whose concentration increases due to the thrombolysis process. When the cross-linking of fibrin is degraded, the resulting fragment has an E subunit and two D subunits. The D-Dimer examination is more specific in detecting the presence of fibrin clot breakdown process and does not increase from circulating fibrinogen. ${ }^{9}$ The availability of fibrinrelated markers is different in each health center. This study aimed to find the agreement of the diagnosis of DIC based on the ISTH and JMHW criteria and correlation analysis of parameters of D-dimer and FDP in sepsis to help clinician in decide which criteria is better to use.

\section{Methods}

A cross-sectional study was held from August 2019-April 2020 in Dr. Hasan Sadikin General Hospital on patients aged above 18 years with a diagnosis of sepsis based on clinical diagnosis written by clinician in the laboratory order forms. The study was approved by Health Ethics Research Committee Dr. Hasan Sadikin General Hospital number LB.02.01/X.6.5/365/2020.

Hemolysis, icteric, and lipemia (turbidity of the sample caused by accumulation of lipoprotein particles) samples were excluded. Hematology and hemostasis sample were analyzed. Hematology parameter which used in ISTH and JMHW was platelet level that measured by impedance principle using XN1000-Hematology Analyzer (Sysmex Co, Kobe, Japan). In ISTH, D-dimer and PT prolongation were measured. Meanwhile, on JMHW, FDP and PT-INR were analyzed. Fibrinogen count was done on that two citeria. Hemostasis analysis 
D Audiyananda et al: Agreement of Overt Disseminated Intravascular Coagulation in Sepsis Patient between ISTH and Haemostasis and JMHW Criteria

was done using H 2600 Automatic Coagulation Analyzer (Maccura Biotechnology Co, Chengdu, China).

The results of the examination would be assessed to determine the condition of DIC overt based on the total ISTH score $\geq 5$ and JMHW $\geq 7$. We conducted total sampling of all cases and include 35 subjects that meet the inclusion and exclusion criteria. The normality test was carried out to determine the distribution of the data, then the Cohen's Kappa consistency test analysis was carried out on the ISTH and JMHW criteria and the F-Dimer and FDP correlation analysis with the Spearman test using the SPSS 17.0 program.

\section{Results}

There were 35 subjects that fit the criteria in this study with a description of the characteristics listed in Table 1.
The mean age of subjects on this study was above 50 years. The percentage of sex in the subject was almost the same. The cause of most sepsis was due to respiratory infections by $60 \%$. Most patients have thrombocytopenia condition accompanied by prolongation of PT for 5.3 seconds with normal fibrinogen value. The median $\mathrm{D}$-Dimer value increased 20 times from the normal value while the FDP increased 3 times from the normal range.

Based on the percentage score of each variable on the ISTH criteria, half of total subjects gain 2 scores for platelets and prolongation of PT. Most of subjects gain zero score for the fibrinogen parameter. In the D-Dimer parameter, most of the subjects had the highest score.

Based on the JMHW criteria, almost half of the subjects gain score 3 for the platelets parameter and score 2 for PT-INR. For FDP, most of subjects gain score 3.

According to Table 4, there were 19 subjects diagnosed as overt DIC and 4 subjects were

Table 1 Patient Characteristic

\begin{tabular}{lcc}
\hline \multicolumn{1}{c}{ Characteristics } & (n=35) & Mean/Median (Min.-Max.) \\
\hline Age & & $53.2 \pm 16.3$ \\
Gender & 15 & \\
$\quad$ Male & 20 & \\
$\quad$ Female & & \\
Type of disease & 21 & \\
$\quad$ Respiratory infection sepsis & 7 & \\
Gastrointestinal sepsis & 2 & \\
Urinary tract sepsis & 5 & \\
Sepsis due to Infection of other organs & & \\
ISTH Criteria & $31(88.6)$ & \\
$\quad$ Overt DIC & $4(11.4)$ & \\
$\quad$ Non-overt DIC & & \\
JMHW criteria & 19 & \\
Overt DIC & 16 & $5.3(0-106)$ \\
Non-overt DIC & & $1.7(1.0-9.0)$ \\
Laboratorium Parameter & & $220(45-833)$ \\
Platelets (10 $/ \mathrm{uL})$ & & $10.6(1.8-70.2)$ \\
PT prolongation (seconds) & & $32.7(3.6-121)$ \\
PT-INR & & \\
Fibrinogen (mg/dL) & & \\
D-Dimer (mg/L) & & \\
FDP (mg/L) & & \\
\hline
\end{tabular}


D Audiyananda et al: Agreement of Overt Disseminated Intravascular Coagulation in Sepsis Patient between ISTH and Haemostasis and JMHW Criteria

Table 2 Variable Score based on ISTH Criteria

\begin{tabular}{ccccc}
\hline \multirow{2}{*}{ Score } & Platelets & PT Prolongation & Fibrinogen & D-Dimer \\
\cline { 2 - 5 } & $\mathbf{n = 3 5}$ & $\mathbf{n = 3 5}$ & $\mathbf{n = 3 5}$ & $\mathbf{n = 3 5}$ \\
\hline 0 & 7 & 11 & 25 & 0 \\
1 & 10 & 8 & 10 & 1 \\
2 & 18 & 16 & & 4 \\
3 & & & & 30 \\
\hline
\end{tabular}

Table 3 Variable Score based on JMHW Criteria

\begin{tabular}{ccccc}
\hline & Platelets & PT-INR & Fibrinogen & FDP \\
\cline { 2 - 5 } & $\mathbf{n = 3 5}$ & $\mathbf{n = 3 5}$ & $\mathbf{n = 3 5}$ & $\mathbf{n = 3 5}$ \\
\hline 0 & 6 & 6 & 22 & 3 \\
1 & 8 & 12 & 4 & 6 \\
2 & 5 & 17 & 9 & 12 \\
3 & 16 & & & 14 \\
\hline
\end{tabular}

diagnosed as non-overt DIC on both criteria with the results of kappa coefficient of 0.266 (p 0.021) means fair agreement.

The parameters that distinguish between ISTH and JMHW criteria were the parameters of fibrin-related markers like D-dimer and FDP. In this study, Spearman correlation test was used due to abnormal distribution of the data.

Table 5 showing the correlation between the FDP and D-dimer. The Spearman correlation showed that there was a positive relationship between the D-Dimer with the FDP, whereas D-Dimer increases, the FDP will increase significantly $(\mathrm{p}<0.001)$.

The correlation between FDP and D-Dimer based on its score is showed on Table 6. There is a positive correlation between the score of D-Dimer with a score of FDP ( $p$ 0.003). There is a parallel increase of D-Dimer and FDP.

\section{Discussion}

In this study, there is no significant difference in the occurrence of DIC based on age and sex according to a study conducted by Levi et al. That DIC can occur at all ages and races and there is no predisposition to gender content. $^{10}$ Most sepsis in this study is caused by respiratory infection. In line with cohort studies by Cilloniz et al, $61 \%$ of patients with severe respiratory tract infections caused by bacteria or viruses, the possibility of sepsis occur due to inflammation continuously and the decline of the immune system. ${ }^{11}$

TheISTH criteria have more subjects with overt DIC than the JMHW criteria, 31 vs 19 subjects. It is possibly due to smaller score required in ISTH criteria compared to JMHW criteria in diagnosis of overt DIC. Based on laboratory parameter data on the ISTH and JMH W criteria, there was a decrease in the number of platelets with a median of $48 \times 10^{3} / \mu \mathrm{L}$. Only 2 subjects showed normal platelets. The majority of the decrease in platelet count is due to the use of platelets in the DIC to maintain the integrity of the blood vessels and activate the subsequent coagulation system. Excessive platelet activation related to

Table 4 ISTH and JMHW Criteria Agreement

\begin{tabular}{|c|c|c|c|c|}
\hline \multirow[b]{2}{*}{ ISTH } & \multicolumn{2}{|c|}{ JMHW } & \multirow{2}{*}{$\begin{array}{c}\text { Kappa } \\
\text { Coefficient }\end{array}$} & \multirow[b]{2}{*}{ P Value } \\
\hline & $\begin{array}{c}\text { Overt DIC } \\
n=19\end{array}$ & $\begin{array}{c}\text { Non-Overt DIC } \\
n=16\end{array}$ & & \\
\hline Overt DIC & 19 & 12 & 0.266 & 0.021 \\
\hline Non-overt DIC & 0 & 4 & & \\
\hline
\end{tabular}


Table 5 FDP and D-Dimer Mean Correlation

\begin{tabular}{lcc}
\hline & \multicolumn{2}{c}{ D-Dimer (mg/dL) } \\
\cline { 2 - 3 } & $\mathbf{r}$ & P-value* \\
\hline FDP (mg/dL) & 0.88 & $<0.001$ \\
\hline *) Spearman rank & \multicolumn{3}{c}{}
\end{tabular}

Table 6 FDP and D-Dimer Score Correlation

\begin{tabular}{lcc}
\hline & \multicolumn{2}{c}{ D-Dimer (mg/dL) } \\
\cline { 2 - 3 } & $\mathbf{r}$ & P-value* $^{*}$ \\
\hline FDP (mg/dL) & 0.603 & 0.003 \\
\hline
\end{tabular}

*) Spearman rank

organ damage when sepsis cause of immune cells recruitment and inflammation, the formation of thrombus in the capillaries, as well as a direct cytotoxic effect mediated by platelet-derived microparticles. ${ }^{1}$ which is probably implicated in the pathogenesis of organ dysfunction in patients with sepsis. Inflammation not only leads to initiation and propagation of coagulation activity, but coagulation also markedly influences inflammation. Molecular mechanisms that play a role in inflammation-induced effects on coagulation have been recognized in much detail. Pro-inflammatory cells and cyto- and chemokines can activate the coagulation system and downregulate crucial physiological anticoagulant mechanisms. Initiation of coagulation activation and consequent thrombin generation is caused by expression of tissue factor on activated monocytes and endothelial cells and is ineffectually offset by tissue factor pathway inhibitor. At the same time, endothelialassociated anticoagulant pathways, in particular the protein C system, is impaired by proinflammatory cytokines. Also, fibrin removal is severely obstructed by inactivation of the endogenous fibrinolytic system, mainly as a result of upregulation of its principal inhibitor, plasminogen activator inhibitor type 1 (PAI-1

Fibrinogen levels in the majority of subjects gain score of $0(\geq 100 \mathrm{mg} / \mathrm{dL})$ at ISTH criteria 25 of 35 and JMHW with a score of $0(\geq 1.50 \mathrm{mg} /$ $\mathrm{dL}$ ) were 22 of 35 . Median fibrinogen found in normal level may as impact of inflammation or infection increased fibrinogen level as acute phase reactants. Fibrinogen as a parameter marker of DIC has a low sensitivity and specificity. ${ }^{5}$ Only 10 of 35 subjects in ISTH criteria and 11 of 35 subjects in JMHW criteria which have fibrinogen level $\leq 100 \mathrm{mg} / \mathrm{dL}$.

The median D- Dimer in this study is
$10.6 \mathrm{mg} / \mathrm{L}$, which is a 20 -fold increase from the cut off value. There is 30 of 35 subjects that gain a score of 3 on the ISTH criteria ( $\geq 4$ $\mathrm{mg} / \mathrm{L}$ ). In the FDP parameter, it was found that a median of $32.7 \mathrm{mg} / \mathrm{L}$ increased 3 times from the cut off value. A total of 14 of 35 of subjects showed a score of $3(\geq 40 \mathrm{mg} / \mathrm{L})$ on the JMHW criteria. Increased D-dimer and FDP as fibrinrelated marker in this study is consistent with Wang et al study that showed an increase in D-dimer in $98.7 \%$ of patients and increase of FDP in $94.1 \%$ patients with DIC due to sepsis in the ICU. ${ }^{12}$

In this study, $85.7 \%$ of the subjects have higher levels of D-dimer $\geq 4 \mathrm{mg} / \mathrm{L}$ (score 3), 14 of 35 of the subjects have high levels of FDP $\geq 40 \mathrm{mg} / \mathrm{L}$ (score 3), and 12 of 35 with the FDP levels 20-40 $\mathrm{mg} / \mathrm{L}$ (score 2). This might raise due to strong correlation between the D-Dimer and FDP. The results of the study are consistent $r$ with study from Sato et al, FDP positively correlated with D-Dimer. In Sato et al, increase in FDP and D-Dimer occurred in parallel. The increase in D-Dimer and FDP indicates the coagulation process and fibrinolysis activation. ${ }^{13}$

The proportion of subjects with an FDP score of 3 (highest score) was lower than the D-Dimer in this study was probably due to the FDP peak level earlier than the D-Dimer and the FDP halflife was shorter compared to D-Dimer. The halflife of D-Dimer is 4.5 times longer than FDP. It is due to complex cross-linked fibrin structure takes longer to be removed from the body. ${ }^{14} \mathrm{D}$ dimers, fibrinogen degradation products (FgDP

The PT prolongation and PT-INR of two criteria showed the distribution of scores almost evenly. The percentage of subjects based on the PT prolongation in the ISTH criteria was 11 of 35 subjects (score $0 / \leq 3$ seconds), 8 of 35 subjects (score 1/3-6 seconds) and 16 of 35 subjects (score $2 / \geq 6$ seconds ), while PT-INR on the JMHW criteria was $17.1 \%$ (score $0 / \leq 1.25$ ), 12 of 35 subjects (score $1 / 1.25-1.67$ ) and 12 of 35 subjects (score $2 / \geq 1.67$ ).

In this study, there are fair agreement of 0.266 between ISTH and JMHW criteria. The less high agreement value is probably due to differences in the weight of the scores from the two systems and the differences in scores, especially on the platelet, D-Dimer, and FDP between the two criteria. The study also shows strong correlation between FDP and D-Dimer in sepsis patients. There are fair agreement of DIC diagnosis and strong correlation between FDP and D-Dimer in sepsis patients with criteria ISTH and JMHW. 
Both criteria are equally able to assist clinicians in determining the type of DIC in sepsis patients depending on the availability of the type of fibrin-related markers in each health centers. If there is discrepancy between the two criteria, then its use depends on the phase of disease. The JMHW criteria are used better during the early phase of DIC because of FDP peak earlier and have shorter half life than D-Dimer that used in ISTH criteria. ${ }^{14}$

This study only analyzes data based on laboratory results but clinical symptoms such as bleeding or organ failure were not included in the calculation of the JMHW criteria scoring. There may be differences in the results of the analysis in comparing the two criteria by including the clinical symptoms as variables so that further research needs to be done.

\section{Acknowledgments}

Support for this study was provided under Maccura Biotechnology Co (PT Indarum Astaguna). The author(s) received the following financial support for the research, authorship, and/or publication of this article.

\section{References}

1. Levi M, van der Poll T. Coagulation and sepsis. Thromb Res. 2017;149:38-44.

2. Longo D, Fauci A, Kasper D, Hauser S, Jameson L, Loscalzo J. Coagulation disorders. In: Arruda VR; High KA, editors. Harrison principles intemal medicine. 20th ed. New York: McGraw-Hill Medical; 2018.

3. Toh C-H, Yasir A, .Abrams ST. Current Pathological and Laboratory considerations in the diagnosis of disseminated intravascular coagulation. Ann Lab Med. 2016;36:505-12.

4. Iba T, Di Nisio M, Thachil J, Wada H, Asakura $\mathrm{H}$, Sato K, et al. A proposal of the modification of Japanese Society on Thrombosis and Hemostasis (JSTH) Disseminated Intravascular Coagulation (DIC) Diagnostic Criteria for Sepsis-Associated DIC. Clin Appl Thromb. 2018;24(3):439-45.

5. DIC subcommittee of the Japanese Society on Thrombosis and Hemostasis, Asakura $\mathrm{H}$, Takahashi H, Uchiyama T, Eguchi Y, Okamoto $\mathrm{K}$, et al. Proposal for new diagnostic criteria for DIC from the Japanese Society on thrombosis and hemostasis. Thromb J. 2016;14(1):42.

6. Toh JMH, Ken-Dror G, Downey C, Abrams ST. The clinical utility of fibrin-related biomarkers in sepsis. Blood Coagul Fibrinolysis Int J Haemost Thromb. 2013;24(8):839-43.

7. Ha SO, Park SH, Hong S-B, Jang S. Performance evaluation of five different disseminated intravascular coagulation (DIC) diagnostic criteria for predicting mortality in patients with complicated sepsis. J Korean Med Sci. 2016;31(11):1838.

8. Stang LJ. D-dimer and fibrinogen/fibrin degradation products. Methods Mol Biol Clifton NJ. 2013;992:415-27.

9. Riley RS, Gilbert AR, Dalton JB, Pai S, McPherson RA. Widely used types and clinical applications of d-dimer assay. Lab Med. 2016;47(2):90-102.

10. Hunt BJ. Bleeding and coagulopathies in critical care. N Engl J Med. 2014 ;370(9):84759.

11. Cillóniz C, Dominedò C, Magdaleno D, Ferrer M, Gabarrús A, Torres A. Pure viral sepsis secondary to community-acquired pneumonia in adults: risk and prognostic factors. J Infect Dis. 2019;220(7):1166-171.

12. Wang Z, Li X, Zhu R, Zhang ZD, Ma XC. A reevaluation of diagnostic efficacy of International Society of Thrombosis and Haemostasis and Japanese Association for Acute Medicine criteria for the diagnosis of sepsis disseminated intravascular coagulation. Zhonghua Nei Ke Za Zhi. 2019;58(5):355-60.

13. Sato N, Takahashi H, Shibata A. Fibrinogen/ fibrin degradation products and D-dimer in clinical practice: Interpretation of discrepant results. Am J Hematol. 1995;48(3):168-74.

14. Tanswell P, Nieuwenhuizen W, Seifried E. Pharmacokinetics of degradation products of fibrin and fibrinogen during alteplase therapy of acute myocardial infarction. Fibrinolysis. 1993;7(6):408-15. 